\title{
Keefektifan PBL seting kolaboratif ditinjau dari prestasi belajar aljabar, kemampuan berpikir kritis, dan kecemasan siswa
}

\author{
Tety Dwi Setyaningsih ${ }^{1}$, Agus Maman Abadi ${ }^{2}$ \\ ${ }^{1}$ SMA Negeri 1 Maos. Jalan Raya Maos No.484, Maos, Kabupaten Cilacap, 53255, Indonesia. \\ ${ }^{2}$ Jurusan Pendidikan Matematika, Universitas Negeri Yogyakarta. \\ Jalan Colombo No. 1, Karangmalang, Yogyakarta, 55281, Indonesia \\ * Corresponding Author. E-mail: tetydwi@gmail.com \\ Received: 20 October 2016; Revised: 14 March 2018; Accepted: 31 December 2018
}

\begin{abstract}
Abstrak
Penelitian ini bertujuan untuk mendeskripsikan mana yang lebih efektif antara PBL setting kolaboratif kelompok dan berpasangan ditinjau dari prestasi belajar aljabar, kemampuan berpikir kritis, dan kecemasan siswa. Penelitian ini adalah penelitian quasi eksperimen dengan desain pretest-postest nonequivalent comparison-group design. Populasi dalam penelitian ini adalah seluruh siswa kelas VII SMP Negeri 3 Kalasan yang terdiri dari empat kelas. Kelas VII C dan VII D ditentukan sebagai sampel secara acak. Dari kedua kelas tersebut diberi instrumen pretest dan postest tentang prestasi belajar aljabar, kemampuan berpikir kritis dan angket kecemasan siswa. Untuk menguji keefektifan pembelajaran digunakan uji one sample t-test. Untuk menguji perbedaan keefektifan digunakan uji MANOVA dan untuk mengetahui pembelajaran mana yang lebih efektif digunakan uji independent sample t-test. Hasil penelitian menunjukkan: (1) PBL seting kolaboratif kelompok maupun berpasangan masing-masing efektif ditinjau dari prestasi belajar aljabar, kemampuan berpikir kritis, dan kecemasan siswa, (2) PBL seting kolaboratif kelompok lebih efektif dibandingkan PBL seting kolaboratif berpasangan ditinjau dari prestasi belajar aljabar, namun tidak terdapat perbedaan keefektifan ditinjau dari kemampuan berpikir kritis dan kecemasan siswa.
\end{abstract}

Kata Kunci: $P B L$, kolaboratif kelompok, kolaboratif berpasangan, aljabar, berpikir kritis, kecemasan

\section{The effectiveness of PBL with collaborative setting in terms of algebraic achievement, critical thinking ability, and math anxiety}

\begin{abstract}
This study aimed to describe which was more effective between $P B L$ with grouped collaborative setting or paired collaborative setting in terms of the algebraic achievement, critical thinking ability, and mathematics anxiety. This research was quasi-experimental with the pretest-posttest nonequivalent comparison-group design. The research population included all $7^{\text {th }}$ grade students of SMP Negeri 3 Kalasan which consisted of four classes. Two classes were randomly established as the sample. Before and after the treatment, these two classes were given a pretest and posttest of algebraic achievements, critical thinking ability, and and questionnaire of math anxiety. To test the effectiveness of this study, the researcher used one sample t-test; to examine differences in the effectiveness, the researcher used MANOVA; to determine which learning model was more effective, the researcher used the independent sample t-test. The results of this study show that: (1) the PBL with grouped and paired collaborative setting were effective in terms of the algebraic achievements, critical thinking ability, and mathematics anxiety, (2) the PBL with grouped collaborative setting was more effective than that using the PBL with paired collaborative setting in terms of algebraic achievement, but no difference in the effectiveness in terms of critical thinking ability and math anxiety

Keywords: PBL, grouped collaborative, paired collaborative, algebraic, critical thinking ability, math anxiety

How to Cite: Setyaningsih, T., \& Abadi, A. (2018). Keefektifan PBL seting kolaboratif ditinjau dari prestasi belajar aljabar, kemampuan berpikir kritis, dan kecemasan siswa. Jurnal Riset Pendidikan Matematika, 5(2), 190200. doi:https://doi.org/10.21831/jrpm.v5i2.11300
\end{abstract}

Permalink/DOI: https://doi.org/10.21831/jrpm.v5i2.11300 


\section{Jurnal Riset Pendidikan Matematika, 5 (2), 2018 - 191}

Tety Dwi Setyaningsih, Agus Maman Abadi

\section{PENDAHULUAN}

Matematika sebagai salah satu mata pelajaran di sekolah dapat digunakan sebagai sarana untuk menciptakan sumber daya manusia yang berkualitas. Matematika sebagai bidang pengetahuan yang berkembang dengan cepat, secara terus menerus diterapkan di berbagai lapangan pekerjaan dan pendidikan (National Council of Teachers of Mathematics, 2000, p. 4). Perkembangan IPTEK yang pesat adalah berkat dukungan matematika. Landasan dukungan adalah disebabkan karena kekuatan matematika pada struktur dan penalarannya.

Perkembangan matematika sering merintis kemungkinan penerapannya yang baru pada berbagai bidang kehidupan. Sayangnya banyak siswa belum dapat merasakan manfaat matematika dalam berbagai bidang kehidupan. Hingga kini mata pelajaran matematika di sekolah masih dianggap sebagai pelajaran yang menakutkan, termasuk bagi siswa SMP. Banyak siswa SMP merasa kesulitan belajar matematika dan cenderung mempunyai nilai yang rendah. The Trends on International Mathematics and Science Study (TIMSS) pada tahun 2011 melaporkan bahwa rata-rata skor matematika siswa sekolah menengah pertama (SMP) tingkat 8 di Indonesia adalah 386, ini jauh di bawah nilai centerpoint (median) 500, sehingga Indonesia menempati peringkat 58 dari 63 peserta (Mullis, Martin, Foy, \& Arora, 2012, p. 42). Pencapaian skor yang tergolong masih rendah ini patutlah untuk ditelusuri penyebabnya pada masing-masing materi pokok dari matematika. Seperti dinyatakan dalam TIMSS Mathematics Framework 2015 bahwa ada empat materi pokok dalam matematika untuk siswa kelas menengah pertama yaitu bilangan (number), aljabar (algebra), geometri (geometry), serta data dan peluang (data and chance) (Mullis \& Martin, 2013, p. 19).

TIMSS juga mengalokasikan target penilaian untuk masing-masing materi pokok tersebut, yaitu $30 \%$ untuk bilangan, $30 \%$ untuk aljabar, 20\% untuk geometri, dan 20\% untuk data dan peluang. Berdasarkan persentase tersebut dapat dilihat bahwa materi pokok bilangan dan aljabar mendapatkan persentase target cukup besar yaitu $30 \%$. Hal ini dapat menjadi acuan bahwa kedua materi pokok tersebut perlu untuk mendapat perhatian khusus dalam rangka usaha peningkatan skor matematika siswa di Indonesia. Provinsi Daerah Istimewa Yogyakarta adalah salah satu provinsi di Indonesia yang memiliki prestasi cukup tinggi, tetapi apabila ditelusuri lebih lanjut salah satu Kabupaten di Daerah Istimewa Yogyakarta yaitu Kabupaten Sleman masih belum mencapai skor yang memuaskan. Hal ini dapat dilihat dari hasil perolehan skor untuk UN SMP Tahun Pelajaran 2014/2015 Kabupaten Sleman dengan persentase peguasaan materi untuk masing-masing materi pokok seperti terlihat pada Tabel 1.

Tabel 1. Persentase Penguasaan materi Soal Matematika UN SMP Tahun Pelajaran 2014/2015

\begin{tabular}{lccc}
\hline $\begin{array}{c}\text { Materi yang } \\
\text { Diuji }\end{array}$ & $\begin{array}{c}\text { Rata-rata } \\
\text { Kabupaten }\end{array}$ & $\begin{array}{c}\text { Rata-rata } \\
\text { Provinsi } \\
\text { DIY }\end{array}$ & $\begin{array}{c}\text { Rata-rata } \\
\text { Nasional }\end{array}$ \\
\hline $\begin{array}{l}\text { Operasi } \\
\text { Bilangan } \\
\text { Operasi }\end{array}$ & 65,36 & 63,30 & 60,64 \\
$\begin{array}{l}\text { Aljabar } \\
\text { Bangun }\end{array}$ & 59,97 & 58,00 & 57,28 \\
$\begin{array}{l}\text { Geometris } \\
\text { Statistika dan }\end{array}$ & 57,02 & 55,19 & 52,04 \\
Peluang & 64,49 & 63,87 & 60,78 \\
\hline
\end{tabular}

Berdasarkan data pada Tabel 1, dapat dilihat untuk materi pokok bilangan skor rata-rata yang diperoleh siswa di Kabupaten Sleman adalah 65,36 hal ini lebih baik jika dibandingkan dengan skor rata-rata untuk materi pokok aljabar yaitu 59,97. Bahkan untuk skala provinsi maupun nasional skor rata-rata untuk materi pokok aljabar selalu lebih rendah dibandingkan dengan materi pokok bilangan.

Rendahnya skor rata-rata untuk materi pokok aljabar dimungkinkan karena siswa pada tingkatan sekolah menengah pertama belum terbiasa untuk mengolah informasi dan melakukan operasi dalam bentuk aljabar. Hal ini sejalan dengan pendapat dari Krismanto \& Rochmitawati (2009, p. 1) bahwa ketika dalam tingkatan sekolah dasar siswa mempelajari aritmetika dan ilmu hitung dengan menggunakan lambang bilangan atau angka-angka dimana siswa dengan langsung dapat membayangkan seberapa besar yang dilambangkan tersebut. Karena bahasa aljabar menggunakan simbol yang bukan hanya angka melainkan juga variabel, maka siswa merasa kesulitan untuk dapat menyelesaikan permasalahan terkait bentuk aljabar. Inilah mengapa prestasi belajar siswa dalam materi pokok aljabar lebih rendah jika dibandingkan dengan materi pokok lain. Hal ini perlu menjadi sorotan bahwa perlunya dilakukan sebuah tindakan untuk meningkatkan prestasi belajar aljabar siswa.

Salah satu SMP di Kabupaten Sleman yang masih perlu untuk mendapat sorotan adalah 
SMP Negeri 3 Kalasan. Data hasil Ulangan Akhir Semester untuk Tahun Pelajaran 2015/2016 menunjukkan bahwa masih banyak siswa kelas VII SMP Negeri 3 Kalasan yang memperoleh nilai matematika di bawah KKM yang ditetapkan sekolah yaitu 75. Hal ini ditunjukkan dengan pencapaian skor rata-rata untuk keempat kelas yang masih jauh di bawah batas KKM yaitu 75 . Rendahnya prestasi belajar siswa kelas VII di SMP Negeri 3 Kalasan dimungkinkan karena adanya kecemasan matematika dalam diri siswa. Hal ini didukung dari hasil wawancara pada tanggal 21 Desember 2015 dengan guru matematika kelas VII yang menyebutkan bahwa beberapa siswa merasa takut saat akan menghadapi tes atau ulangan matematika. Sehingga untuk meningkatkan prestasi belajar siswa, perlu adanya suatu upaya untuk mengatasi kecemasan siswa.

Menurut hasil penelitian Sherman dan Wither (2003, p. 149), menyebutkan adanya hubungan antara prestasi siswa dan kecemasan matematika. Siswa yang memiliki kecemasan matematika cenderung memiliki prestasi yang rendah. Munculnya kecemasan saat pelajaran matematika dapat disebabkan oleh beberapa hal. Greenwood (Thijsse, 2002, p. 13) menegaskan bahwa "the principal cause of maths anxiety lies in the teaching methodologies used to convey basic mathematical skills". Penyebab dari kecemasan saat belajar matematika adalah ketidaktepatan dalam menerapkan model pembelajaran. Ketidaktepatan model yang digunakan menyebabkan munculnya kecemasan pada siswa (Arem, 2010, p. 20). Fakta umum yang dapat dijumpai di sekolah menengah adalah sebagian besar pengajaran matematika masih menerapkan paradigma lama melalui pembelajaran teacher centered tanpa banyak memperhatikan kemungkinan penerapan model pembelajaran lain yang memungkinkan siswa aktif dalam belajar.

Permendikbud Nomor 81A Tahun 2013 menjelaskan bahwa prinsip kegiatan pembelajaran adalah memberikan kesempatan kepada peserta didik untuk mengembangkan potensi mereka menjadi kemampuan yang semakin lama semakin meningkat dalam sikap, pengetahuan, dan keterampilan yang diperlukan dirinya untuk hidup dan untuk bermasyarakat, berbangsa, serta berkontribusi pada kesejahteraan hidup umat manusia (Menteri Pendidikan dan Kebudayaan Republik Indonesia, 2013). Oleh karena itu, kegiatan pembelajaran diarahkan untuk memberdayakan semua potensi peserta didik mencapai kompetensi yang diharapkan.
Kurikulum 2013 menganut pandangan dasar bahwa peserta didik harus memiliki kemampuan untuk secara aktif mencari, mengolah, mengkonstruksi, dan menggunakan pengetahuan. Proses pembelajaran terdiri atas lima pengalaman belajar pokok yaitu mengamati, menanya, mengumpulkan informasi, mengasosiasi, dan mengkomunikasikan (Kementerian Pendidikan dan Kebudayaan Republik Indonesia, 2013, p. 6). Oleh karena itu, guru sebagai pendidik perlu melaksanakan pembelajaran matematika dengan cara siswa aktif membangun suatu pengetahuan. Selain itu, guru juga turut serta menciptakan kondisi dan situasi yang memungkinkan siswa untuk mengembangkan kompetensi dan kemampuannya yaitu dengan memilih dan menerapkan model pembelajaran yang tepat.

Salah satu model pembelajaran yang dapat digunakan untuk meningkatkan peran aktif sekaligus keterampilan berpikir siswa adalah adalah Problem Based Learning (Farhan \& Retnawati, 2014; Jailani, Sugiman, \& Apino, 2017). Problem Based Learning merupakan model pembelajaran yang berdasarkan pada masalah. Dengan pembelajaran yang dimulai dari masalah, siswa belajar suatu konsep dan prinsip sekaligus memecahkan masalah. Menurut Arends (2004, p. 396) Problem Based Learning (PBL) merupakan pembelajaran yang menghadapkan siswa dengan masalah autentik yang dapat menuntun siswa dalam penyelidikan dan inkuiri. Arends (2004, p. 407) menyatakan bahwa di dalam pelaksanaan PBL tidak terdapat aturan baku mengenai cara pengelompokan siswa dalam pembelajaran. Adapun sintak PBL dalam penelitian ini meliputi lima tahapan, yaitu: (1) mengorientasikan siswa pada masalah, (2) mengorganisasikan siswa untuk belajar, (3) membimbing penyelidikan individual maupun kelompok, (4) mengembangkan dan menyajikan hasil karya, dan (5) menganalisis dan mengevaluasi proses penyelesaian masalah.

Penelitian terdahulu, yang dilakukan oleh Norman dan Schmidt menyatakan bahwa PBL lebih baik dalam meningkatkan kemampuan berpikir kritis dibandingkan dengan kurikulum tradisional (Romdoni, \& Supriyoko, 2017; Searight \& Searight, 2009, p. 70). Hal ini sejalan dengan hasil penelitian dari Nugraha dan Mahmudi (2015, p. 13) yang menunjukkan bahwa pembelajaran berbasis masalah dapat meningkatkan kemampuan berpikir kritis siswa. Berpikir kritis sebagai salah satu bentuk kemampuan berpikir tingkat tinggi, harus dimiliki oleh setiap orang termasuk siswa. Ennis (1996, p. 166) mengemukakan bahwa siswa yang berpikir 


\section{Jurnal Riset Pendidikan Matematika, 5 (2), 2018 - 193}

Tety Dwi Setyaningsih, Agus Maman Abadi

kritis adalah siswa yang mampu mengidentifikasi, menggeneralisasi dan mengevaluasi penalaran. Menurut Paul dan Elder (2007, p. 4), seorang yang berpikir secara kritis mampu memunculkan pertanyaan dan masalah yang vital dan merumuskannya secara jelas dan tepat. Kemudian kaitannya dalam pembelajaran matematika sesuai dengan pendapat dari Glazer (2001, p. 13) bahwa berpikir kritis dalam matematika adalah kemampuan dan disposisi untuk menggabungkan pengetahuan sebelumnya, penalaran matematika, dan strategi kognitif untuk menggeneralisasi, membuktikan, atau mengevaluasi situasi matematika yang tidak dikenali secara reflektif. Hal ini yang menjadikan kemampuan berpikir kritis sangat perlu dimiliki oleh setiap siswa untuk dapat menghadapi permasalahan-permasalahan khususnya permasalahan matematika.

Berdasarkan hasil wawancara dengan guru matematika kelas VII di SMP Negeri 3 Kalasan, diketahui bahwa kemampuan berpikir kritis siswa belum menjadi sorotan utama dalam pembelajaran matematika di sekolah. Hal ini didukung oleh hasil prapenelitian pada hari Senin tanggal 25 Januari 2016 di SMP Negeri 3 Kalasan tentang kemampuan berpikir kritis, dimana telah dipaparkan satu soal yang memuat indikator kemampuan berpikir kritis. Salah satu indikator kemampuan berpikir kritis adalah mendeteksi kesalahan, hasil prapenelitian menunjukkan bahwa dari 32 siswa, hanya 10 diantaranya yang mampu mendeteksi kesalahan. Hal ini menunjukkan bahwa sebagian besar siswa belum terbiasa menyelesaikan soal-soal tipe berpikir kritis yang cenderung tergolong soal non rutin, kebanyakan siswa hanya terbiasa menyelesaikan soal yang setipe dengan contoh soal yang diberikan guru atau contoh soal yang terdapat pada buku-buku pelajaran. Sehingga dengan adanya prapenelitian ini dapat menjadi indikasi bahwa kemampuan berpikir kritis siswa masih perlu ditingkatkan.

Dalam rangka usaha meningkatkan kemampuan berpikir kritis siswa, model pembelajaran berbasis masalah yang dirasa tepat dan sesuai untuk diterapkan, ternyata memiliki kelebihan dan kekurangan. Dalam hal ini pembelajaran berbasis masalah memiliki kendala yakni dalam menyikapi keheterogenan yakni pada aspek kemampuan awal, kecepatan berpikir dan motivasi (Widjajanti \& Wahyudin, 2011, p. 404). Guru dalam hal ini harus dapat menjamin hak setiap siswa untuk memperoleh pembelajaran yang bermakna untuk setiap siswa, untuk mengatasi dampak dari keheterogenan siswa maka diperlukan model pembelajaran yang memberi kesempatan lebih besar pada siswa untuk dapat saling berinteraksi dan saling belajar dari siswa lainnya, maka model pembelajaran kolaboratif dapat menjadi pilihan. Dalam pembelajaran kolaboratif siswa belajar berpasangan atau membentuk kelompok kecil dalam mencapai tujuan. Mereka membentuk kelompok belajar, tidak belajar sendiri (Barkley, Cross, \& Major, 2007, p. 4).

Watskins, Eileen, dan Lodge (2007, p. 94) menyatakan struktur pembelajaran kolaboratif adalah sebagai berikut: (1) formulate, pada tahap ini siswa diminta untuk menjawab secara individual pertanyaan yang diajukan, (2) share, pada tahap ini siswa saling membagi jawaban mereka dengan teman dalam grup, (3) listen, pada tahap ini siswa mendengarkan jawaban dari teman dan mencatat persamaan dan perbedaannya, (4) created, pada tahap ini siswa mengambil ide yang menurutnya terbaik dan mempresentasikan di depan kelas. Penelitian Mandusic dan Blaskovic (2015, p. 428) menunjukkan pembelajaran kolaboratif memberikan pengaruh yang kuat terhadap perkembangan kemampuan berpikir kritis siswa melalui diskusi, klarifikasi dan evaluasi dari ideide yang muncul.

Berdasarkan penelitian yang relevan tentang pembelajaran kolaboratif, penulis tertarik untuk menggabungkan antara problem based learning yang menjadikan masalah sebagai titik awal pembelajaran yang selanjutnya akan dilaksanakan secara kolaboratif. Pelaksanaan pembelajaran kolaboratif pada penelitian ini dilaksanakan dalam dua tipe kelompok yaitu secara berpasangan dan kelompok kecil. Pembagian kelompok secara berpasangan akan membuat kontrol diri lebih tinggi, menjadikan individu lebih aktif (Dzhogleva \& Lamberton, 2014, p. 2). Namun, lebih sedikit ide yang muncul jika kelompok diseting berpasangan. Sedangkan, dalam kelompok kecil akan lebih banyak ide, saling berbagi dalam kelompok, sehingga akhirnya anggota kelompok mempunyai kemampuan yang sama dalam pemahaman.

Memandang kelebihan dan kekurangan untuk masing-masing seting, maka penelitian ini bertujuan untuk (1) mengetahui keefektifan problem based learning dengan seting kolaboratif kelompok dan berpasangan ditinjau dari prestasi belajar aljabar SMP, kemampuan berpikir kritis dan kecemasan siswa, (2) mengetahui manakah yang lebih efektif antara problem based learning seting kolaboratif kelompo Diharapkan teori pembentukan kelompok dalam pembelajaran 
dengan seting kolaboratif ini dapat menjadi salah satu referensi bagi guru untuk mengelola pembelajaran.

\section{METODE}

Jenis penelitian ini adalah eksperimen semu (quasi experiment), mengingat prestasi belajar aljabar, kemampuan berpikir kritis, dan kecemasan siswa dapat dipengaruhi oleh banyak faktor. Selain itu, tidak dimungkinkan untuk mengambil sampel secara acak atau untuk alasan kepraktisan atau alasan etika (Kirk, 1995, p. 6). Kelompok-kelompok yang diberikan perlakuan adalah kelas-kelas yang telah dibentuk sebelumnya untuk kegiatan pembelajaran setiap hari di sekolah.

Populasi dalam penelitian ini adalah seluruh siswa kelas VII SMP Negeri 3 Kalasan tahun pelajaran 2015/2016 yang terdiri dari 4 kelas. Pengambilan sampel dilakukan dengan memilih dua kelas yang ditentukan secara acak. Kelas yang menjadi sampel dalam penelitian yaitu kelas VII C dan kelas VII D. Selanjutnya dari kedua kelas dipilih secara acak untuk menentukan perlakuan yang diberikan sehingga terpilih kelas VII $\mathrm{C}$ untuk diterapkan pembelajaran dengan problem based learning dengan seting kolaboratif kelompok kecil dan kelas VII D diterapkan pembelajaran dengan problem based learning dengan seting kolaboratif berpasangan.

Desain yang digunakan dalam penelitian ini yaitu pretest-posttest nonequivalent comparison-group design. Kelas yang digunakan dalam penelitian ini terdiri atas dua kelas, yaitu kelas yang diberi perlakuan dengan PBL kolaboratif kelompok dan kelas yang diberi perlakuan dengan PBL kolaboratif berpasangan. Masing-masing kelas pada desain penelitian ini akan diberikan tes sebelum perlakuan dan setelah perlakuan. Tes yang diberikan adalah tes prestasi belajar aljabar, tes kemampuan berpikir kritis, dan angket kecemasan siswa.

Data-data yang dideskripsikan dalam penelitian ini adalah data tes prestasi belajar aljabar, data tes kemampuan berpikir kritis, dan data angket kecemasan siswa. Data yang telah diperoleh dihitung nilai rata-ratanya kemudian diinterpretasi ke dalam kriteria-kriteria yang telah ditetapkan dan ditentukan persentasenya.

Data prestasi belajar aljabar diperoleh melalui pengukuran dengan instrumen tes yang berbentuk pilihan ganda dengan 25 soal. Hasil yang diperoleh dikonversi sehingga menjadi nilai dengan rentang antara 0 sampai dengan 100 . Skor tersebut kemudian digolongkan dalam kriteria berdasarkan kriteria ketuntasan minimal (KKM) yang ditetapkan oleh sekolah.

Data kemampuan berpikir kritis siswa diperoleh melalui tes yang berupa 3 soal uraian. Hasil yang diperoleh dikonversi sehingga menjadi nilai dengan rentang antara 0 sampai dengan 100. Skor tersebut kemudian digolongkan dalam kriteria berdasarkan kriteria ketuntasan minimal (KKM) yang ditetapkan berdasarkan pertimbangan peneliti.

Instrumen kecemasan siswa berisi 25 item pernyataan. Setelah memperoleh data mengenai kecemasan siswa, total skor kecemasan siswa terhadap matematika dikategorikan berdasarkan Tabel 2.

Tabel 2. Kriteria Kecemasan Siswa

\begin{tabular}{ll}
\hline \multicolumn{1}{c}{ Interval } & Kategori \\
\hline $\mathrm{Mi}+1,5 \mathrm{SDI}>\mathrm{X}$ & Sangat Tinggi \\
$\mathrm{Mi}+0,5 \mathrm{SDI}<\mathrm{X} \leq \mathrm{Mi}+1,5 \mathrm{SDI}$ & Tinggi \\
$\mathrm{Mi}-0,5 \mathrm{SDI}<\mathrm{X} \leq \mathrm{Mi}+0,5 \mathrm{DI}$ & Cukup \\
$\mathrm{Mi}-1,5 \mathrm{SDI}<\mathrm{X} \leq \mathrm{Mi}-0,5 \mathrm{SDI}$ & Rendah \\
$\mathrm{X} \leq \mathrm{Mi}-1,5 \mathrm{SDI}$ & Sangat Rendah \\
\hline
\end{tabular}

(Azwar, 2013, p.163)

Keterangan:

$M_{i}=$ Rata-rata ideal

$=\frac{1}{2} \times($ skor maksimum ideal + skor minimum ideal $)$

$\mathrm{SDI}=$ Standar baku ideal

$=\frac{1}{6} \times($ skor maksimum ideal - skor minimum ideal $)$ skor maksimum ideal $=\sum$ butir kriteria $\times$ skor tertinggi skor minimum ideal $=\sum$ butir kriteria $\times$ skor terendah

Untuk mengetahui keefektifan dari masing-masing pembelajaran ditinjau dari masingmasing variabel, maka digunakan one sample $t$ test. Selanjutnya untuk mengetahui perbedaan keefektifan antara kelas PBL seting kolaboratif kelompok kecil dan PBL seting kolaboratif berpasangan digunakan uji MANOVA (kriteria Hotelling's Trace) dengan kriteria keputusan pada taraf signifikansi 5\%. Jika hasil uji MANOVA menunjukkan bahwa terdapat perbedaan signifikan antara kedua kelompok perlakuan, maka dilakukan analisis lanjutan yaitu independent sample t-test yang bertujuan untuk mengetahui perlakuan mana yang lebih efektif ditinjau dari ketiga variabel terikat. Sebelum dilakukan Uji MANOVA terlebih dahulu harus dipenuhi dua asumsi multivariat yaitu asumsi kenormalan multivariat dan asumsi homogenitas multivariat. Pemeriksaan normalitas dilakukan dengan cara nilai jarak kuadrat (jarak mahalanobis $d_{i}^{2}$ ). Uji homogenitas dilakukan melalui uji Box's $M$ test menggunakan program SPSS 20 for windows. 
Jurnal Riset Pendidikan Matematika, 5 (2), 2018 - 195

Tety Dwi Setyaningsih, Agus Maman Abadi

\section{HASIL DAN PEMBAHASAN}

Hasil

Data yang diperoleh dalam penelitian ini yakni data hasil tes prestasi belajar aljabar, tes kemampuan berpikir kritis, dan angket kecemasan siswa. Tabel 3 menyajikan deskripsi data hasil tes prestasi belajar aljabar siswa.

Tabel 3. Deskripsi Data Hasil Tes Prestasi Belajar Aljabar

\begin{tabular}{lcccc}
\hline \multirow{2}{*}{ Deskripsi } & \multicolumn{3}{c}{$\begin{array}{c}\text { PBL Kolaboratif } \\
\text { Kelompok }\end{array}$} & $\begin{array}{c}c \\
\text { B Kerpasangan }\end{array}$ \\
\cline { 2 - 5 } & Pre & Post & Pre & Post \\
\hline Rata-rata & 51,88 & 86,25 & 50,38 & 78,12 \\
Maks & 76 & 100 & 76 & 96 \\
Nilai ideal & 100 & 100 & 100 & 100 \\
maks & 28 & 52 & 24 & 48 \\
Min & & & \\
\hline
\end{tabular}

Berdasarkan data yang ditunjukkan pada Tabel 3, skor rata-rata pretest pada kelas PBL kolaboratif kelompok adalah 51,88, sedangkan pada kelas PBL kolaboratif berpasangan adalah 50,38. Skor rata-rata postest pada kelas PBL kolaboratif kelompok adalah 86,25, sedangkan pada kelas PBL kolaboratif berpasangan adalah 78,12 . Nilai ideal maksimum untuk hasil pencapaian prestasi belajar aljabar adalah 100, untuk hasil pretest skor prestasi pada kelas PBL kolaboratif kelompok dan kelas PBL kolaboratif berpasangan masing-masing hanya mencapai skor 76, sedangkan untuk hasil postest untuk kedua kelas ada siswa yang berhasil mencapai skor maksimal yaitu 100. Selanjutnya, data hasil tes kemampuan berpikir kritis disajikan dalam Tabel 4.

Tabel 4 menunjukkan bahwa rata-rata skor pretest untuk kelas PBL kolaboratif kelompok adalah 35, sedangkan untuk kelas PBL kolaboratif berpasangan adalah 41,15. Sedangkan ratarata skor postest untuk kelas PBL kolaboratif kelompok adalah 77,92, sedangkan untuk kelas PBL kolaboratif berpasangan adalah 82,19. Nilai maksimum yang dapat diperoleh siswa sesuai dengan besar nilai maksimum ideal yaitu 100 .
Tabel 4. Deskripsi Data Hasil Tes Kemampuan Berpikir Kritis

\begin{tabular}{|c|c|c|c|c|}
\hline \multirow{3}{*}{ Deskripsi } & \multicolumn{4}{|c|}{ PBL Kolaboratif PBL Kolaboratif } \\
\hline & \multicolumn{2}{|c|}{ Kelompok } & \multicolumn{2}{|c|}{ Berpasangan } \\
\hline & Pre & Post & Pre & Post \\
\hline Rata-rata & 35,0 & 77,92 & 41,15 & 82,19 \\
\hline Maks & 60 & 100 & 70 & 100 \\
\hline $\begin{array}{l}\text { Nilai ideal } \\
\text { maks }\end{array}$ & 100 & 100 & 100 & 100 \\
\hline Min & 13,33 & 53,33 & 16,67 & 53,33 \\
\hline
\end{tabular}

Data tersebut adalah data cakupan secara umum dari tingkat kemampuan berpikir kritis siswa, adapun jika dianalisis untuk setiap komponen dan indikator dari kemampuan berpikir kritis siswa maka diperoleh data pada Tabel 5.

Berdasarkan Tabel 5, terlihat bahwa terdapat peningkatan skor untuk setiap indikator berpikir kritis. Untuk kelas PBL kolaboratif kelompok peningkatan paling tinggi ada pada indikator 'mencari hubungan antar informasi', pada saat pretest persentase siswa yang menjawab benar pada indikator tersebut adalah $24,7 \%$, setelah dilaksanakan pembelajaran dan diambil data postest diperoleh persentase sebesar 78,5\%. Sedangkan untuk kelas PBL kolaboratif berpasangan, peningkatan tertinggi ada pada indikator 'membuat kesimpulan yang tepat'. Pada saat pretest persentase siswa yang menjawab benar pada indikator tersebut hanya $11,5 \%$, sedangkan hasil postest menunjukkan persentasenya meningkat menjadi $66,7 \%$. Sehingga dapat disimpulkan melalui pembelajaran dengan PBL seting kolaboratif, siswa mengalami peningkatan kemampuan untuk mencari hubungan antar informasi dan membuat kesimpulan yang tepat. Tentunya ini juga didukung dengan peningkatan kemampuan siswa dalam 'mengidentifikasi informasi yang akurat', meskipun untuk indikator ini peningkatannya tidak begitu tinggi.

Kemudian, data hasil pretest dan postest untuk kecemasan siswa pada kedua kelas eksperimen disajikan dalam Tabel 6.

Tabel 5. Persentase Capaian Kemampuan Berpikir Kritis Siswa untuk Tiap Indikator

\begin{tabular}{clcccc}
\multirow{2}{*}{ Komponen } & \multicolumn{1}{c}{ Indikator } & \multicolumn{2}{c}{ PBL Kolaboratif Kelompok } & \multicolumn{2}{c}{ PBL Kolaboratif Berpasangan } \\
\cline { 2 - 5 } & & Pre & Post & Pre & Post \\
\hline \multirow{2}{*}{ Analisis } & Identifikasi informasi & $77,1 \%$ & $99,5 \%$ & $75,5 \%$ & $98,4 \%$ \\
& hubungan antar informasi & $24,7 \%$ & $78,5 \%$ & $33,0 \%$ & $77,8 \%$ \\
\multirow{2}{*}{ Evaluasi } & Mendeteksi kesalahan & $52,1 \%$ & $89,6 \%$ & $54,2 \%$ & $96,9 \%$ \\
& Alasan logis & $17,2 \%$ & $67,7 \%$ & $24,0 \%$ & $71,9 \%$ \\
& Aturan untuk konteks baru & $32,3 \%$ & $83,3 \%$ & $47,9 \%$ & $84,4 \%$ \\
\hline
\end{tabular}


Tabel 6. Deskripsi Data Hasil Angket Kecemasan Siswa

PBL Kolaboratif PBL Kolaboratif

\begin{tabular}{lcccc}
\multirow{2}{*}{ Deskripsi } & \multicolumn{2}{c}{ Kelompok } & \multicolumn{2}{c}{ Berpasangan } \\
\cline { 2 - 5 } & Pre & Post & Pre & Post \\
\hline Rata-rata & 88,94 & 77,38 & 85,97 & 76,22 \\
Maks & 108 & 94 & 108 & 95 \\
Nilai ideal & 125 & 125 & 125 & 125 \\
maks & & & & \\
Min & 67 & 60 & 52 & 54 \\
\hline
\end{tabular}

Berdasarkan Tabel 6, rata-rata skor angket kecemasan siswa sebelum perlakuan pada kelas PBL Kolaboratif Kelompok adalah 88,94 yang masuk dalam interval $83,33<\mathrm{X} \leq 100$ atau berada pada kategori tinggi dan pada kelas PBL kolaboratif berpasangan adalah 85,97 juga berada pada interval yang sama atau termasuk kategori tinggi. Rata-rata skor angket kecemasan siswa setelah perlakuan pada kelas PBL kolaboratif kelompok adalah 77,38 yang masuk dalam interval $66,67<\mathrm{X} \leq 83,33$ atau berada pada kategori sedang dan pada kelas PBL kolaboratif berpasangan adalah 76,22 juga berada pada interval yang sama atau termasuk kategori sedang. Tampak bahwa pada kedua kelas eksperimen terjadi penurunan rata-rata skor sebelum dan setelah perlakuan.

Data tersebut adalah deskripsi hasil angket kecemasan siswa secara keseluruhan, adapun data hasil angket sebelum dan sesudah perlakuan untuk masing-masing aspek kecemasan siswa disajikan dalam Tabel 7.

Tabel 7. Persentase Kecemasan Siswa untuk Tiap Aspek

\begin{tabular}{|c|c|c|c|c|}
\hline \multirow[t]{2}{*}{ Aspek } & \multicolumn{2}{|c|}{$\begin{array}{c}\text { PBL } \\
\text { Kolaboratif } \\
\text { Kelompok }\end{array}$} & \multicolumn{2}{|c|}{$\begin{array}{c}\text { PBL } \\
\text { Kolaboratif } \\
\text { Berpasangan }\end{array}$} \\
\hline & Pre & Post & Pre & Post \\
\hline $\begin{array}{l}\text { Materi } \\
\text { Matematika }\end{array}$ & $75,3 \%$ & $64,8 \%$ & $71,8 \%$ & $62,0 \%$ \\
\hline $\begin{array}{l}\text { Pembelajaran } \\
\text { Matematika }\end{array}$ & $66,5 \%$ & $58,6 \%$ & $64,7 \%$ & $56,8 \%$ \\
\hline $\begin{array}{l}\text { Guru } \\
\text { Matematika }\end{array}$ & $68,5 \%$ & $59,4 \%$ & $67,1 \%$ & $59,9 \%$ \\
\hline $\begin{array}{l}\text { Tes/Ujian } \\
\text { Matematika }\end{array}$ & $73,8 \%$ & $64,4 \%$ & $71,2 \%$ & $64,6 \%$ \\
\hline
\end{tabular}

Berdasarkan Tabel 7 terlihat bahwa untuk kelas PBL kolaboratif kelompok, penurunan kecemasan siswa paling besar ada pada aspek materi matematika yaitu dari persentase skor $75,3 \%$ menjadi $64,8 \%$, penurunannya sebesar $10,5 \%$. Begitu pula untuk kelas PBL kolaboratif berpasangan, penurunan kecemasan paling besar juga ada pada aspek materi matematika yaitu dari persentase skor $71,8 \%$ menjadi $62 \%$, penurunannya sebesar $9,8 \%$. Hal ini mengindikasikan bahwa dengan pembelajaran PBL kolaboratif baik secara kelompok maupun berpasangan, rasa cemas siswa akan materi matematika berkurang. Ini dikarenakan siswa yang bekerja sama secara berpasangan saling tergerak dan termotivasi serta merasa bertanggung jawab untuk bisa memahami materi dan menyelesaikan permasalahan yang diberikan. Sedangkan siswa yang bekerja dalam kelompok dapat mencapai pemahaman materi dengan baik dengan adanya kerjasama dan saling berbagi pengetahuan dalam kelompok.

Data penelitian ini selanjutnya dianalisis untuk mengetahui keefektifan dari masingmasing kelompok pembelajaran terhadap prestasi belajar aljabar, kemampuan berpikir kritis, dan kecemasan siswa. Analisis keefektifan ini menggunakan uji one sample t-test. Sedangkan untuk mengetahui perbandingan keefektifan dari masing-masing kelompok belajar akan dilakukan uji univariat. Sebelum dilakukan uji one sample t-test dan uji univariat dengan kriteria Bonferroni maka terlebih dahulu dilakukan uji MANOVA dengan melihat nilai signifkasi pada Hotelling's Trace maka pemenuhan asumsi-asumsi multivariat perlu dilakukan. Berikut hasil analisis asumsi normalitas dan homogenitas multivariat baik sebelum maupun sesudah perlakuan ditunjukkan pada Tabel 8 dan Tabel 9.

Tabel 8. Hasil Uji Normalitas Multivariat

\begin{tabular}{lcc}
\hline \multicolumn{1}{c}{ Kelas } & $\begin{array}{c}\mathrm{d}_{\mathrm{i}}{ }^{2} \text { pretest } \\
(\%)\end{array}$ & $\begin{array}{c}\mathrm{d}_{\mathrm{i}}{ }^{2} \text { posttest } \\
(\%)\end{array}$ \\
\hline $\begin{array}{l}\text { PBL kolaboratif } \\
\text { kelompok }\end{array}$ & 46,87 & 50 \\
$\begin{array}{l}\text { PBL kolaboratif } \\
\text { berpasangan }\end{array}$ & 53,13 & 53,13 \\
\hline
\end{tabular}

Tabel 9. Hasil Uji Box’s M

\begin{tabular}{ccc}
\hline & Pretest & Postest \\
\hline Box's M & 6,748 & 9,558 \\
$F$ & 1,065 & 1,509 \\
Sig. & 0,381 & 0,171 \\
\hline
\end{tabular}

Hasil analisis menunjukkan bahwa semua data baik tes awal maupun tes akhir berdistribusi normal dan kelompok-kelompok data terkait berdasarkan hasil uji Box's M memiliki matrikskovarians yang sama. Karena kedua asumsi terpenuhi maka uji MANOVA dan uji univariat dapat dilakukan. Selanjutnya dilakukan uji MANOVA untuk Mengetahui perbedaan mean masing-masing kelompok baik sebelum maupun sesudah perlakuan dengan melihat kriteria Hotelling's Trace. Berikut data hasil uji 
MANOVA baik sebelum maupun sesudah perlakuan yang ditunjukkan pada Tabel 10 .

Tabel 10. Hasil Uji MANOVA

\begin{tabular}{ccc}
\hline & Pretest & Postest \\
\hline$F$ & 2.132 & 8.104 \\
Sig. & 0.106 & 0.000 \\
\hline
\end{tabular}

Berdasarkan Tabel 10 diperoleh informasi bahwa nilai signifikansi $F$ sebelum perlakuan lebih dari 0,05, ini menujukan bahwa $\mathrm{H}_{0}$ diterima atau dengan kata lain tidak terdapat perbedaan kemampuan awal siswa antara kelas yang diajarkan dengan PBL kolaboratif kelompok maupun berpasangan ditinjau dari prestasi belajar aljabar, kemampuan berpikir kritis, dan kecemasan siswa, sedangkan nilai signifikansi $F$ setelah perlakuan kurang dari 0,05 , ini menunjukan bahwa $\mathrm{H}_{0}$ ditolak atau dengan kata lain terdapat perbedaan keefektifan pembelajaran dengan PBL kolaboratif kelompok dan PBL kolaboratif berpasangan ditinjau dari prestasi belajar aljabar, kemampuan berpikir kritis, dan kecemasan siswa.

Untuk mengetahui keefektifan masing-masing kelompok belajar, maka akan dilakukan uji one sample t-test sedangkan untuk mengetahui perbandingan keefektifan dari masing-masing kelompok belajar terhadap prestasi belajar aljabar, kemampuan berpikir kritis, dan kecemasan siswa, maka dilakukan uji univariat.Uji univariat dilakukan terhadap data-data yang diperoleh setelah perlakuan dengan menghitung nilai $t$ (independent sample t-test). Adapun hasil uji one sample $t$ test dan uji univariat akan disajikan berturut-turut dalam Tabel 11 dan Tabel 12 .

Tabel 11. Uji Kefektifan

\begin{tabular}{llcc}
\hline \multicolumn{1}{c}{ Kelas } & \multicolumn{1}{c}{ Variable } & $t$ & \multicolumn{1}{c}{ Sig. } \\
\hline PBL kolaboratif & Prestasi Belajar & 6,429 & 0,000 \\
kelompok & $\begin{array}{l}\text { aljabar } \\
\text { Berpikir kritis }\end{array}$ & 4,534 & 0,000 \\
& Kecemasan & $-4,689$ & 0,000 \\
PBL kolaboratif & Prestasi Belajar & 1,824 & 0,000 \\
kelompok & aljabar & & \\
& Berpikir kritis & 6,454 & 0,000 \\
& Kecemasan & $-4,460$ & 0,000 \\
\hline
\end{tabular}

Berdasarkan Tabel 11, nilai signifikansi $t$ untuk semua aspek tinjauan baik prestasi belajar aljabar, kemampuan berpikir kritis, dan kecemasan siswa kurang dari 0,05 , ini menunjukan bahwa $\mathrm{H}_{0}$ ditolak atau dengan kata lain pembelajaran dengan PBL kolaboratif kelompok maupun berpasangan efektif ditinjau dari prestasi belajar aljabar, kemampuan berpikir kritis, dan kecemasan siswa.
Tabel 12. Uji Perbedaan Keefektifan

\begin{tabular}{lc}
\hline \multicolumn{1}{c}{ Variabel Independen } & Sig (2-tailed) \\
\hline Prestasi Belajar aljabar & 0,001 \\
Berpikir kritis & 0,053 \\
Kecemasan & 0,326 \\
\hline
\end{tabular}

Berdasarkan Tabel 12, terlihat bahwa nilai signifikansi prestasi belajar aljabar adalah 0,001 dimana kurang dari 0,05 . Jadi $\mathrm{H}_{0}$ ditolak, artinya pembelajaran PBL seting kolaboratif kelompok lebih efektif daripada PBL seting kolaboratif berpasangan ditinjau dari prestasi belajar aljabar. Nilai signifikansi kemampuan berpikir kritis adalah 0,053 dimana lebih dari 0,05. Jadi $\mathrm{H}_{0}$ diterima, artinya tidak terdapat perbedaan keefektifan pembelajaran PBL seting kolaboratif kelompok dan PBL seting kolaboratif berpasangan ditinjau dari kemampuan berpikir kritis. Nilai signifikansi kecemasan siswa adalah 0,326 dimana lebih dari 0,05 . Jadi $\mathrm{H}_{0}$ diterima, artinya tidak terdapat perbedaan keefektifan pembelajaran PBL seting kolaboratif kelompok sama efektif dibandingkan PBL seting kolaboratif berpasangan ditinjau dari kecemasan siswa.

\section{Pembahasan}

Beberapa model dan pendekatan pembelajaran perlu dikembangkan demi tercapainya kualitas pendidikan yang lebih baik. Namun, belum dapat dipastikan model pembelajaran apa yang paling sesuai dengan karakteristik suatu bidang ilmu, khususnya untuk matematika. Karena matematika memiliki banyak cabang ilmu yang saling terkait seperti aljabar, geometri, kalkulus, dan statistika. Oleh karena itu, perlu dilakukan suatu penelitian untuk mengetahui apakah sebuah model pembelajaran sesuai untuk diterapkan dan efektif untuk meningkatkan hasil belajar pada sebuah cabang bidang ilmu. Pada penelitian ini, diterapkan pembelajaran matematika menggunakan problem based learning dengan seting kolaboratif pada materi aljabar. Beberapa hal yang diteliti dalam penelitian antara lain keefektifan PBL seting kolaboratif kelompok dan berpasangan ditinjau dari prestasi belajar aljabar, kemampuan berpikir kritis, dan kecemasan siswa. Kemudian ditentukan apakah ada perbedaan keefektifan diantara kedua kelas eksperimen tersebut.

Berdasarkan hasil uji statistik one sample $t$-test, pembelajaran matematika dengan PBL seting kolaboratif kelompok efektif ditinjau dari prestasi belajar aljabar, kemampuan berpikir kritis, dan kecemasan siswa. Hal ini karena materi persamaan linear satu variabel dan aritmetika 


\section{Jurnal Riset Pendidikan Matematika, 5 (2), 2018 - 198}

Tety Dwi Setyaningsih, Agus Maman Abadi

sosial yang diajarkan dikaitkan dengan konteks kehidupan siswa sehari-hari, sehingga selama proses pembelajaran siswa dapat berpartisipasi aktif melalui kegiatan diskusi kelompok. Hal ini sejalan dengan hasil penelitian Linda (2004, p. 4) bahwa dalam kelompok kecil akan ada lebih banyak ide, saling berbagi dalam kelompok yang akhirnya membuat anggota kelompok mempunyai kemampuan yang hampir sama sehingga dapat meningkatkan pengetahuan, pemahaman, dan prestasi belajar.

Pembelajaran dengan metode berkelompok diyakini mampu mengurangi rasa cemas yang timbul dalam diri siswa akan susahnya memahami materi matematika. Karena mereka yang tadinya merasa tidak paham akan terbantu oleh teman sekelompoknya yang mampu memahami materi tersebut.

Pada kelas yang berbeda, pembelajaran matematika dengan PBL seting kolaboratif berpasangan juga efektif ditinjau dari prestasi belajar, kemampuan berpikir kritis, dan kecemasan siswa. Ini disebabkan oleh beberapa hal, diantaranya karena siswa dituntut untuk aktif selama proses pembelajaran. Setiap siswa harus mampu menguasai materi yang diajarkan, karena paling tidak dia harus berbagi ilmu pengetahuan dengan siswa lain yang duduk di sebelahnya. Jumlah kelompok yang relatif kecil (2 orang) ini terkadang justru dapat memancing siswa untuk lebih bertanggung jawab dan bukan hanya bergantung pada anggota kelompok lain seperti yang terjadi pada kelas kelompok 4-5 orang. Hal ini sejalan dengan pendapat Karcher dan Lewis (2002, p. 20) bahwa dengan metode berpasangan akan menjadikan siswa lebih aktif mengeksplor kemampuannya, pembagian kelompok secara berpasangan akan memberikan kesempatan siswa untuk lebih memaksimalkan usahanya karena anggotanya yang hanya 2 orang.

Hasil yang diperoleh melalui uji $T^{2}$ Hotelling menunjukkan bahwa terdapat perbedaan keefektifan antara kelas yang menerapkan pembelajaran PBL kolaboratif kelompok dan pembelajaran PBL kolaboratif berpasangan ditinjau dari prestasi belajar aljabar, kemampuan berpikir kritis, dan kecemasan siswa. Adapun hasil uji lanjut yang telah dilakukan dengan uji independent sample t-test menunjukkan bahwa pembelajaran PBL kolaboratif kelompok lebih efektif dari pembelajaran PBL kolaboratif berpasangan ditinjau dari variabel prestasi belajar aljabar. Namun, apabila ditinjau dari variabel kemampuan berpikir kritis dan kecemasan siswa pembelajaran PBL kolaboratif kelompok sama efektifnya dengan pembelajaran PBL kolaboratif berpasangan. Hal ini nampak dari hasil tes setelah perlakuan yang menunjukkan hasil pencapaian yang tidak jauh berbeda antara kelas PBL seting kolaboratif kelompok dan berpasangan ketika ditinjau dari perolehan skor kemampuan berpikir kritis dan kecemasan siswa.

Terdapat beberapa hal yang diduga menyebabkan pembelajaran PBL kolaboratif kelompok lebih efektif dibandingkan PBL kolaboratif berpasangan ditinjau dari prestasi belajar aljabar. Pembelajaran secara berkelompok mampu memunculkan lebih banyak ide sehingga lebih mudah untuk menemukan penyelesaian permasalahan yang diberikan. Selain itu, adanya saling berbagi dalam kelompok membuat semua anggota kelompok mampu mencapai pemahaman yang sama, sehingga siswa dengan tingkat pemahaman materi rendah akan lebih terbantu. Keaktifan siswa dalam diskusi kelompok memberi dampak pada kemampuan berpikir kritis siswa, dimana siswa tidak hanya duduk sekedar melengkapi anggota kelompok melainkan bekerja sama dalam setiap proses penyelesaian masalah. Hal ini sejalan dengan pendapat Lie (2005, p. 46) yang menyatakan beberapa kekurangan pembelajaran yang dilaksanakan dengan metode berpasangan, diantaranya apabila pembelajaran dilaksanakan dengan metode berpasangan hanya akan ada sedikit ide yang muncul, apabila timbul perselisihan dalam kelompok maka tidak ada penengah, dan jika kelas di desain secara berpasangan maka akan ada banyak kelompok yang terbentuk, dan menyebabkan terlalu banyak kelompok yang melapor dan harus dimonitor.

\section{SIMPULAN}

Berdasarkan hasil analisis data dan pembahasan, dapat disimpulkan sebagai berikut: (1) pembelajaran matematika dengan PBL seting kolaboratif kelompok efektif ditinjau dari prestasi belajar aljabar, kemampuan berpikir kritis, dan kecemasan siswa; (2) pembelajaran matematika dengan PBL seting kolaboratif berpasangan efektif ditinjau dari prestasi belajar aljabar, kemampuan berpikir kritis, dan kecemasan siswa; (3) pembelajaran matematika dengan PBL seting kolaboratif kelompok lebih efektif dibandingkan PBL seting kolaboratif berpasangan ditinjau dari prestasi belajar aljabar, namun tidak terdapat perbedaan keefektifan antara pembelajaran matematika menggunakan PBL seting kolaboratif kelompok dan pembelajaran matematika menggunakan PBL seting kolaboratif 
berpasangan ditinjau dari kemampuan berpikir kritis dan kecemasan siswa.

\section{DAFTAR PUSTAKA}

Arem, C. (2010). Conquering math anxiety. Belmont, CA: Brooks/Cole

Arends, R. (2004). Learning to teach. New York, NY: Mc Graw Hill.

Azwar, S. (2013). Tes prestasi. Yogyakarta: Pustaka Pelajar

Barkley, E. E., Cross, K. P., \& Major, C. H. (2012). Teknik-teknik pembelajaran kolaboratif. (Terjemahan Narulita Yusron). San Francisco, CA: Jossey-Bass. (Buku asli diterbitkan tahun 2005)

Dzhogleva, H., \& Lamberton, C. T. (2014). Should birds of a feather flock together? Understanding self-control decissions dyads. Journal of Consumer Research, 41(2), 361-380.

Ennis, R. H. (1996). Critical thinking disposition: Their nature and assessability. Informal Logic, 8(2), 165-182.

Farhan, M., \& Retnawati, H. (2014). Keefektifan PBL dan IBL ditinjau dari prestasi belajar, kemampuan representasi matematis, dan motivasi belajar. Jurnal Riset Pendidikan Matematika, 1(2), 227-240. doi:https://doi.org/10.21831/jrpm.v1i2.26 78

Glazer, E. (2001). Using internet primary sources to teach critical thinking skills mathematics. London: Greenwood Press.

Jailani, J., Sugiman, S., \& Apino, E. (2017). Implementing the problem-based learning in order to improve the students' HOTS and characters. Jurnal Riset Pendidikan Matematika, 4(2), 247-259. doi: 10.21831/jrpm.v4i2.17674

Karcher, M. J., \& Lewis, S. S. (2002). Pair counseling: The effects of a dyadic developmental play therapy on interpersonal understanding and externalizing behaviors. International Journal of Play Therapy, 11(1), 19-41.

Kirk, R. E. (1995). Experimental design: Procedural for the behavioral sciences. Belmont, CA: Brooks/Cole Publishing.

Krismanto, A., \& Rochmitawati, R. (2009). Kapita selekta pembelajaran aljabar di kelas VII SMP. Yogyakarta: Depdiknas
Lie, A. (2005). Mempraktikkan cooperative learning di ruang-ruang kelas. Jakarta: Grasindo.

Linda, T. M. (2004). Peranan dinamika kelompok dalam meningkatkan efektivitas kerja tim. Retrieved from http://library.usu.ac.id/download/fkm/fkm -linda3.pdf.

Mandusic, D., \& Blaskovic, L. (2015). The impact of collaborative learning to critically thinking. Trakia Journal of Sciences, 13, 426-428.

Kementerian Pendidikan dan Kebudayaan Republik Indonesia. (2013). Lampiran IV Peraturan Menteri Pendidikan dan Kebudayaan Nomor 81A, tahun 2013, tentang implementasi kurikulum, pedoman umum pembelajaran.

Mullis, I. V., Martin, M. O., Foy, P., \& Arora, A. (2012). TIMSS 2011 international result in mathematics. Chestnut Hill, MA: TIMSS \& PIRLS International Study Center.

Mullis, I. V., \& Martin, M. O. (2013). TIMSS 2015 assessment frameworks. Chestnut Hill, MA: TIMSS \& PIRLS International Study Center.

National Council of Teachers of Mathematics. (2000). Principles and standards for school mathematics. Reston, VA: Author.

Nugraha, T., \& Mahmudi, A. (2015). Keefektifan pembelajaran berbasis masalah dan problem posing ditinjau dari kemampuan berpikir logis dan kritis. Jurnal Riset Pendidikan Matematika, 2(1), 107 - 120. doi:https://doi.org/10.21831/jrpm.v2i1.71 54

Paul, R., \& Elder, L. (2009). The miniature guide to critical thinking-concepts and tools (Thinker's guide). Dillon Beach, CA: Foundation for critical thinking.

Romdoni, M., \& Supriyoko, S. (2017). Penerapan model PBL dengan video untuk meningkatkan minat dan prestasi belajar matematika siswa kelas XMIPA 2 SMAN 1 Minggir pada pokok bahasan eksponen dan logaritma tahun 2016/2017. Wiyata Dharma: Jurnal Penelitian dan Evaluasi Pendidikan, 5(1), 63-69. doi:http://dx.doi.org/10.30738/wiyata dharma.v5i1.3296

Searight, H. R., \& Searight, B. K. (2009). Implementing problem-based learning in 


\section{Jurnal Riset Pendidikan Matematika, 5 (2), 2018 - 200}

Tety Dwi Setyaningsih, Agus Maman Abadi

an undergraduate psychology course. InSight: A Journal of Scholarly Teaching, 4, 69-76.

Sherman, B. F., \& Wither, D. P. (2003). Mathematics anxiety and mathematics achievement. Mathematics Education Research Journal, 15(2), 138-150.

Thijsse, L. J. (2002). The effects of a structured teaching method on mathematics anxiety and achievement of grade eight learners.
(Unpublised master's thesis). University of South Africa.

Watskin, C., Camell, E., \& Lodge, C. (2007). Effective learning in classroom. London, UK: Paul Chapman Publishing.

Widjajanti, D. B., \& Wahyudin, W. (2011). Mengembangkan kemampuan pemecahan masalah dan belief calon guru matematika melalui strategi perkuliahan kolaboratif. Jurnal Cakrawala Pendidikan, 3(3). doi:https://doi.org/10.21831/cp.v3i3.4204. 